\title{
Effect of planting system and seedling number on growth and rice yield rice Inpari-IR-Nutri Zinc
}

\author{
Tietyk Kartinaty ${ }^{*}$, Rustan Massinai, Deden Fardenan, and Riki Warman \\ Assessment Institute for Agricultural Technology of West Kalimantan, Jl. Budi Utomo No. 45 \\ Pontianak 78241 West Kalimantan, Indonesia.
}

\begin{abstract}
Rice Inpari-IR-Nutri Zinc is a biofortified product with a high zinc content compared to other types of rice. This study aimed to obtain the best planting system and the number of seeds in increasing the growth and yield of Inpari IR Nutri Zinc. This study used a Divided Plot Design which was repeated four times. There was a total of 32 treatment combinations. The planting system (S) is placed as the main plot consisting of S1 (4: 1 Legowo Planting System) and S2 (Tile Planting System), while the number of seeds (J) as sub-plots consists of J1 (1 seed), J2 (3) seeds), J3 (3 seeds) and $\mathrm{J} 4$ ( 7 seeds). The planting system and the number of seeds had a significant effect on the variables of plant height, total tiller number, number of productive tillers, the weight of 1,000 seeds, panicle length, and rice production of Inpari IR Nutri Zinc. The use of seeds of 1 and 3 plants produced 4.74 and 4.60 tons/ha. The legowo $4: 1$ planting system had 4.88
\end{abstract}

\section{Introduction}

Efforts to increase rice production to achieve food security continue to encourage the government to achieve sustainable food self-sufficiency. In this case, appropriate cultivation techniques are needed to increase rice productivity by considering environmental aspects and cultivation techniques such as crop establishment, the number of seeds, and varieties that can adapt well to provide a potential high yield.

Inpari Nutri Zinc rice variety is a variety that is rich in $\mathrm{Zn}$ content and functions to overcome stunting. Biofortification is carried out to increase the nutritional value and overcome the iron deficiency in people. It is namely assembling rice varieties with high $\mathrm{Zn}$ content. The Inpari Nutri Zinc rice variety is a variety that is rich in $\mathrm{Zn}$ content and functions to overcome stunting. Inpari IR Nutri Zinc has many advantages over other varieties in terms of $\mathrm{Zn}$ content. Based on the description data issued through the Decree of the Minister of Agriculture in 2019, the $\mathrm{Zn}$ content in this variety is $34.51 \mathrm{ppm}$ while other varieties such as Ciherang contain $24.06 \mathrm{ppm}$. These advantages are expected to contribute to the success of the government's program in overcoming zinc deficiency and minimizing stunting in Indonesia.

The legowo 4:1 planting system is a crop establishment system that pays attention to the array of plants and alternates planting between two or more rice plants and one empty row.

\footnotetext{
* Corresponding author: kartinatytietyk@yahoo.co.id
} 
The goal is to maintain the plant population per unit area and even increase [1]. In principle, the legowo planting system is to increase the population by adjusting the spacing. This planting system also manipulates the layout of the plants so that the clumps of plants are primarily marginal plants. Rice plants on edge will get more sunlight, thus producing higher grain with better quality. In the 4:1 legowo planting method, every four rows of plants are interspersed with an empty row. Still, the spacing in the row is narrowed to half the original spacing. In general, fringe plants show higher yields than those in the inner row. Peripheral plants also show better growth because crop competition between rows can be reduced. The application of the legowo system of planting has several advantages. Namely, sunlight can be used more for the photosynthesis process, fertilization, and controlling plant-disturbing organisms is easier in the hallways. In addition, the legowo system of rice cultivation also increases the plant population [2].

Seeds are one of the technological components that are very influential in increasing rice production. One of the efforts to achieve the above target is through an intensification program by applying appropriate production technology and efficient and profitable production facilities, including using the number of seeds per cluster. Planting a relatively large number of seedlings (5-10 stems per clump, even $>10$ stems per clump) causes competition among rice plants (inter-species competition) which is very hard to obtain. Water, nutrients, $\mathrm{CO} 2, \mathrm{O} 2$, light, and space to grow so that growth will be abnormal. As a result, rice plants become weak, prone to collapse, susceptible to pests and diseases. Further, this situation can reduce grain yields. Meanwhile, the use of a smaller number of seeds (1-3 stems per clump) resulted in: (1) less inter-species competition; and (2) a smaller number of seeds are used, thereby reducing production cost $[3,4]$.

The planting system and the number of seeds in rice cultivation influence the growth and yield of Inpari IR Nutri Zinc rice plants. In this regard, using a planting system and a very optimum number of seeds is necessary to cultivate lowland rice. The purpose of the study was to determine the effect of the planting system and the correct number of seeds to increase the production of lowland rice (Oryza sativa L.) Inpari IR Nutri Zinc variety to obtain the best planting system and the number of seeds in improving growth and yield of Inpari IR Nutri Zinc.

\section{Materials and methods}

The experiment was carried out in Cipta Karya Village, Sungai Betung District, Bengkayang Regency, West Kalimantan, which was carried out from September 2019 to February 2020. The equipment used included: meters, analytical scales, stationery, and work recording sheets. The materials used include rice seeds of the Inpari IR Nutri Zinc variety, including fertilizers, pesticides, herbicides.

This study used a Split-plot Design which was repeated three times. From those two factors, there were 8 treatment combinations with 3 replications to produce 24 treatment plots. The Planting System (S) was placed as the Main Plot, while the number of Seeds (J) was the Sub-plot. The details are as follows: a. As Main Plot: Planting system (S), consists of 2 types, namely: S1 = Legowo $4: 1, \mathrm{~S} 2=$ Tile planting, b. As Sub-plots: The number of seeds consists of 4 types, namely: $\mathrm{J} 1=1$ seed, $\mathrm{J} 2=3$ seeds, $\mathrm{J} 3=5$ seeds, $\mathrm{J} 4=7$ seeds. From these treatments, there were 36 treatment combinations. The combination of treatments can be seen in Table 1. 
Table 1. Combination of Planting System Treatments and Number of Seeds on Inpari IR Nutri Zinc.

\begin{tabular}{lcccc}
\hline \multicolumn{1}{c}{ Treatment } & \multicolumn{4}{c}{ Number of Seeds (J) } \\
\hline & $\mathbf{1}(\mathbf{J 1})$ & $\mathbf{3 ( J 2 )}$ & $\mathbf{5 ( J 3 )}$ & $\mathbf{7 ( J 4 )}$ \\
\hline Planting System $(\mathrm{S})$ & & & & \\
\hline Legowo 4: 1 (S1) & S1J1 & S1J2 & S1J3 & S1J4 \\
\hline Tile (S2) & S2J1 & S2J2 & S2J3 & S2J4 \\
\hline
\end{tabular}

Plant observations included plant height $(\mathrm{cm})$, total tillers (stems), number of productive tillers (stems), the weight of 1,000 seeds (gr), panicle length $(\mathrm{cm})$, and production (tons $/ \mathrm{ha})$. Observations of plant height and total tillers were carried out at the age of 30, 50, 70, and 90 days after planting (DAP), while observations of the number of productive tillers, panicle length, weight of 1,000 seeds, and production were carried out at harvest. The data from the observations of each parameter collected were analyzed using the $\mathrm{F}$ test at a $5 \%$ significance level; if the analysis results showed a significant difference between the treatments, a further test with 5\% BNT was carried out to determine the differences in each treatment [5].

\section{Result and discussion}

The results of statistical analysis In Table 2, the effect of the planting system and the number of seedlings on plant height variables showed a significant impact at 30, 50, 70 Days After Planting (DAP). In contrast, at the observational age of 90 DAP, only the planting system treatment had a significant effect.

High and low growth and plant yields are influenced by two factors, namely internal factors, and external factors. Internal factors are influenced by genetic traits or inherited traits such as plant age, plant morphology, yield, capacity to store food reserves, resistance to disease, etc. External factors are environmental factors, such as climate, soil, and biotic factors. Differences in growth and yields obtained are thought to be caused by one or more of these factors. Internal factors or genetic factors are specific depending on the properties possessed by the plant itself. Plant height is a characteristic of the rice plant influenced by genes from within the plant itself [6].

Table 2. Effect of planting system treatment and number of Inpari IR Nutri Zinc rice seeds on plant height variables at various ages of observation

\begin{tabular}{|c|c|c|c|c|}
\hline \multirow{2}{*}{ Treatments } & \multicolumn{3}{|c|}{ Plant Height $(\mathrm{cm})$, at the age of observation (DAP) } & \multirow[b]{2}{*}{90 DAP } \\
\hline & 30 DAP & 50 DAP & 70 DAP & \\
\hline \multicolumn{5}{|c|}{ Planting System } \\
\hline Legowo 4:1 & $44.75 \mathrm{~b}$ & $72.56 \mathrm{~b}$ & $92.63 \mathrm{~b}$ & $117.19 \mathrm{~b}$ \\
\hline Tile & $43.19 \mathrm{a}$ & $71.75 \mathrm{a}$ & $91.56 \mathrm{a}$ & $113,13 \mathrm{a}$ \\
\hline BNT 5\% & 0.77 & 0.78 & 1.03 & 0.49 \\
\hline \multicolumn{5}{|c|}{ Number of Seeds } \\
\hline 1 Seed & $45.50 \mathrm{~b}$ & $73.13 \mathrm{~b}$ & $93.38 \mathrm{~b}$ & 117.50 \\
\hline 3 Seeds & $45.13 \mathrm{~b}$ & $73.00 \mathrm{~b}$ & $93.00 \mathrm{~b}$ & 115.00 \\
\hline 5 Seeds & $43.13 \mathrm{a}$ & $71.75 \mathrm{a}$ & $91.13 \mathrm{a}$ & 113.75 \\
\hline 7 Seeds & $42.13 \mathrm{a}$ & $70.75 \mathrm{a}$ & $90.88 \mathrm{a}$ & 114.38 \\
\hline BNT 5\% & 1.87 & 1.12 & 1.17 & ns \\
\hline
\end{tabular}

Note: Numbers accompanied by the same letter show no significant difference according to the BNT test 5\%, DAP (days after planting), ns (not significant).

The results of the Honestly Significant Difference (BNT) test are shown in Table 2, namely the observation ages of 30,50,70, and 90 DAP with the legowo 4: 1 planting system showing higher plant heights, namely $44.75 \mathrm{~cm}, 72.56 \mathrm{~cm}, 92,63 \mathrm{~cm}$ and $117.19 \mathrm{~cm}$ 
compared to the tile planting system. The treatment of the number of seeds based on the results of the BNT test showed that the use of 1 and 3 seeds had a higher plant height at the observational ages of 30, 50, 70 DAP. Applying the 4:1 legowo planting system with all rows obtaining insert plants provides an opportunity to increase the population by $20.44 \%$ compared to the tile planting system. Treatment of the number of seeds 1 and 3 plants gave better plant height growth which was suspected that competition between plants in getting sunlight and supply of nutrients was lower to spurred better plant height growth. Based on Aribawa (2012), a Higher plant height resulted in more plant populations in one area. High plant growth does not guarantee high plant productivity. Plants that grow well can absorb nutrients in large quantities. The availability of nutrients in the soil affects plant activities, including photosynthetic activity, to increase growth and production [7].

The number of tillers will be maximized if the plant has good genetic characteristics coupled with favorable environmental conditions or following plant growth and development. Furthermore, it was stated that the spacing also determined the maximum number of tillers because the spacing determines solar radiation, mineral nutrients, and the cultivation of the plant itself. However, genetic factors, as well as environmental factors, also select the productivity of the rice [8].

Table 3. Effect of planting system treatment and number of Inpari IR Nutri Zinc rice seedlings on the variable number of total tillers of plants at various ages of observation

\begin{tabular}{lllll}
\hline \multirow{2}{*}{ Treatment } & \multicolumn{3}{c}{ Total tiller number of plants (stems), at the age of } \\
& \multicolumn{3}{c}{ observation (DAP) } & \\
\cline { 2 - 4 } & 30 DAP & 50 DAP & 70 DAP & 90 DAP \\
\hline Planting System & & & & \\
\hline Legowo 4 : & $9,06 \mathrm{~b}$ & $16,25 \mathrm{~b}$ & $19,06 \mathrm{~b}$ & $19,56 \mathrm{~b}$ \\
Tile & $8,44 \mathrm{a}$ & $14,88 \mathrm{a}$ & $17,13 \mathrm{a}$ & $17,63 \mathrm{a}$ \\
\hline BNT 5\% & 0,62 & 0,53 & 0,70 & 0,49 \\
\hline Number of Seedlings & & & & $19,13 \mathrm{~b}$ \\
\hline 1 Seedling & 8,25 & 15,75 & $18,63 \mathrm{~b}$ & $19,00 \mathrm{~b}$ \\
3 Seedlings & 8,75 & 15,75 & $18,50 \mathrm{~b}$ & $18,00 \mathrm{a}$ \\
5 Seedlings & 9,13 & 15,38 & $17,58 \mathrm{a}$ & $17,88 \mathrm{a}$ \\
7 Seedlings & 8,88 & 15,38 & $17,38 \mathrm{a}$ & 0,49 \\
\hline BNT 5\% & $\mathrm{ns}$ & $\mathrm{ns}$ & 1,02 & \\
\hline
\end{tabular}

Note: Numbers accompanied by the same letter show no significant difference according to the BNT test $5 \%$, DAP (days after planting), ns (not significant).

In table 3, the variance results showed that only the planting system significantly affected the age of observation 30 and 50 DAP. In contrast, at the age of 70 and 90 DAP, the planting system treatment and the number of seedlings had a considerable impact. The results of the BNT test at the 5\% level showed the highest total number of tillers at the age of 30 and 50 DAP in the treatment of the 4:1 legowo planting system, which was 9.06 compared to the tiles planting system. At the age of observation, 70 and 90 DAP showed the legowo planting system treatment, and the number of seeds of 1 and 3 seedlings had a higher total number of tillers. It is suspected that the technology of the legowo planting system utilizes the border effect so that rice plants get more sunlight and can photosynthesize optimally. The use of seeds of 1 and 3 plants gives the plant the ability to photosynthesize with less competition to utilize nutrients to better plant growth to produce more tillers. Wide spacing will increase the capture of solar radiation by the plant canopy, thereby increasing plant growth such as the number of productive tillers, volume, and total root length, growing plant dry weight, and grain weight per clump, but does not affect yield per unit area $[9,10,11]$. 
Table 4 shows that the planting system treatment gave the number of productive tillers, 1,000 seeds weight, panicle length, and higher production than the tiles planting system, 18.13 stems, $25.63 \mathrm{gr}, 27.34 \mathrm{~cm}$, and 4.88 tons/ha, respectively. In comparison, the number of seeds of 1 and 3 seedlings gave the number of productive tillers, the weight of 1,000 seeds, panicle length, and higher production compared to the number of seedlings of 5 and 7 seedlings.

Table 4. Effect of cropping system treatment and the number of Inpari IR Nutri Zinc rice seeds on the number of productive tillers, panicle length, weight of 1,000 seeds, and yield

\begin{tabular}{lllll}
\hline Treatment & $\begin{array}{l}\text { Number of } \\
\text { productive } \\
\text { tillers }\end{array}$ & $\begin{array}{l}\text { Weight } \\
\mathbf{1 , 0 0 0} \text { seeds } \\
\mathbf{( g )}\end{array}$ & $\begin{array}{l}\text { Panicle } \\
\text { Length } \\
\text { (cm) }\end{array}$ & $\begin{array}{l}\text { Yield } \\
\text { (Tons/ha) }\end{array}$ \\
\hline Planting System & & & & \\
\hline Legowo 4 : 1 & $18,13 \mathrm{~b}$ & $25,63 \mathrm{~b}$ & $27,34 \mathrm{~b}$ & $4,88 \mathrm{~b}$ \\
Tile & $16,94 \mathrm{a}$ & $24,75 \mathrm{a}$ & $25,90 \mathrm{a}$ & $4,03 \mathrm{a}$ \\
\hline BNT 5 \% & 0,73 & 0,87 & 0,97 & 0,24 \\
\hline Number of Seedlings & & & & \\
\hline 1 Seedling & $18.13 \mathrm{~b}$ & $25,88 \mathrm{~b}$ & $27,55 \mathrm{~b}$ & $4,74 \mathrm{~b}$ \\
3 Seedlings & $18.38 \mathrm{~b}$ & $25,75 \mathrm{~b}$ & $27,50 \mathrm{~b}$ & $4,60 \mathrm{~b}$ \\
5 Seedlings & $16.88 \mathrm{a}$ & $24,90 \mathrm{a}$ & $25,69 \mathrm{a}$ & $4,23 \mathrm{a}$ \\
7 Seedlings & $16.75 \mathrm{a}$ & $24,00 \mathrm{a}$ & $25,75 \mathrm{a}$ & $4,25 \mathrm{a}$ \\
\hline BNT 5 \% & 0.90 & 1,27 & 1,24 & 0.24 \\
\hline
\end{tabular}

Note: Numbers accompanied by the same letter show no significant difference according to the BNT test $5 \%$, DAP (days after planting), ns (not significant).

The number of productive tillers illustrates the total number of tillers produced previously, where productive tillers are tillers that develop further and produce panicles. The number of productive tillers is determined by the number of tillers that grow before reaching the primordial phase. Still, there may be a chance that the tillers that form the last panicle may not produce panicles that are filled with grains, thus having the opportunity to make empty grain (Wagiyana et al., 2009). In using the number of seeds 1 and 3, the number of productive tillers was more, and it was suspected that the competition of plants in obtaining nutrients, sunlight, and $\mathrm{CO} 2$ was less so that the formation of the number of productive tillers was maximized. The rate of photosynthesis in the canopy is minimal by the availability of $\mathrm{CO} 2$ around the leaves. Therefore, if the number of plants is more in one clump, the leaf positions will coincide, resulting in competition for the use of $\mathrm{CO} 2$ in the area around the leaves [12].

Plant height and number of productive tillers are some of the plant characters that greatly influence the relationship between panicle length and yield. Plants that grow well can absorb nutrients optimally so that in a growing environment where the availability of water and nutrients is sufficient, they can increase the photosynthetic activity of plants so that plant yield growth increases [13].

Planting density is one of the factors that determine the yield of grain per unit area or clump. The legowo planting system can also increase production due to the effect of marginal plants, which are expected to provide high output and better grain quality, increase the number of population/plant clumps per hectare, there is open space for water regulation, increase plants receive optimal sunlight which is helpful in the process of photosynthesis [14]. The utilization of open space in the legowo planting system causes the photosynthesis process to take place effectively in the generative phase. More photosynthetic results are carried to the seeds to yield grain yields [15]. 


\section{Conclusion}

The results showed that the effect of the planting system and the number of seeds had a significant effect on the variables of plant height, total tiller number, number of productive tillers, the weight of 1,000 seeds, panicle length, and rice production of Inpari IR Nutri Zinc. The use of seeds of 1 and 3 plants gave high production of 4.74 and 4.60 tons/ha. The legowo 4: 1 planting system gave a higher production of 4.88 tons/ha than the tile planting system.

\section{References}

1. Suriapermana, dan S. I. Syamsiah, 2012. Tanam jajar legowo pada sistem usahatani minapadi-azola di lahan sawah irigasi. Risalah Seminar Hasil Penelitian dan Pengembangan Tanaman Pangan, Bogor.

2. P.M. Sirrapa. J. Budidaya Pertanian, 7 (2011)

3. A.Gani. Sistem intensifikasi padi (System of Rice Intensification). Pedoman Praktis Bercocok Tanam Padi Sawah dengan Sistem SRI. 2003

4. S.Abdullah. Pengaruh perbedaan jumlah dan umur bibit terhadap pertumbuhan dan hasil padi sawah. Dalam Lamid, Z., et al. (Penyunting). Prosiding Seminar Nasional Penerapan Agroinovasi Mendukung Ketahanan Pangan dan Agribisnis. 2004

5. K.A, Gomez, A.A. Gomez. Statistical Procedures for Agricultural Research. An International Rice Research Institute Book. A wiley Interscience Publication. 1984

6. F.P.Gardner, R.B. Pearce, R.L. Mitchell. Physiology of crop plants. Penterjemah H. Susilo dan Subiyanto. Fisiologi Tanaman Budidaya. Penerbit UI Press. Jakarta. 1991

7. Aribawa. Pengaruh sistem tanam terhadap peningkatan produktivitas padi di lahan sawah dataran tinggi beriklim basah. Balai Pengkajian Teknologi Pertanian (BPTP) Bali. Denpasar. 2012

8. Y.Husana, Pengaruh Penggunaan Jarak Tanam Terhadap Pertumbuhan dan Produksi Padi. 2010

9. B.A. Kurniasih, S. Fatimah, D.A. Purnawati. J. Ilmu Pertanian 15 (2008)

10. XQ.Lin, D.F. Zhu, H.Z. Chen, Y.P. Zhang. 2009. Rice Science 16 (2009)

11. M. Hatta. J. Agrista 16 (2012)

12. N.J. Rosenberg. Microclimate: The Biological Environment. John Wiley. New York.1974.

13. S.Yoshida. Fundamental Of Rice Crop Science. International Rice Research Institute. Los Banos. Laguna. The Philippines. 1981

14. Pangerang. Keuntungan dan kelebihan system jarak tanam jajar legowo padi sawah. PPL Kabupaten Maros. Http//pertanian. Trunojoyo.ac.id. 2013

15. A. Irmayanti. Respons Beberapa Varietas Padi Terhadap Dua Sistem Tanam. Tesis. Program Studi Ilmu-ilmu Pertanian Program Pasca Sarjana. Universitas Tadulako. 2011. 